\title{
ALTERNATIVE DISPUTE RESOLUTION (ADR) VIA SULH PROCESSES
}

\author{
Nor'Adha Abdul Hamid ${ }^{1, *}$ \\ Faculty of Syariah and Law, Kolej Universiti Islam Antarabangsa Selangor (KUIS), \\ Bandar Seri Putra, 43000 Kajang Selangor, Malaysia. \\ Faculty of Science and Information Technology, Kolej Universiti Islam Antarabangsa Selangor (KUIS), \\ Bandar Seri Putra, 43000 Kajang Selangor, Malaysia. \\ *For correspondence; Tel. + (60) 193096889, (Email: noradha@kuis.edu.my) \\ Mohamad Hafifi Hassim ${ }^{2}$ \\ Faculty of Syariah and Law, Kolej Universiti Islam Antarabangsa Selangor (KUIS), \\ Bandar Seri Putra, 43000 Kajang Selangor, Malaysia. \\ Faculty of Science and Information Technology, Kolej Universiti Islam Antarabangsa Selangor (KUIS), \\ Bandar Seri Putra, 43000 Kajang Selangor, Malaysia. \\ (Email: hafifi@kuis.edu.my) \\ Norazla Ab Wahab ${ }^{3}$ \\ Faculty of Syariah and Law, Kolej Universiti Islam Antarabangsa Selangor (KUIS), \\ Bandar Seri Putra, 43000 Kajang Selangor, Malaysia. \\ (Email: norazla@kuis.edu.my) \\ Tuan Nurhafiza Raja Abdul Aziz ${ }^{4}$ \\ Kolej Universiti Islam Antarabangsa Selangor (KUIS), Bandar Seri Putra, 43000 Kajang Selangor, Malaysia. \\ (Emai: tuan.nurhafiza@ kuis.edu.my)

\section{Roslinda Ramli ${ }^{5}$} \\ Faculty of Science and Information Technology, Kolej Universiti Islam Antarabangsa Selangor (KUIS), \\ Bandar Seri Putra, 43000 Kajang Selangor, Malaysia. \\ (Emai: roslinda@kuis.edu.my) \\ Siti Noor Ahmad ${ }^{6}$ \\ Faculty of Science and Information Technology, Kolej Universiti Islam Antarabangsa Selangor (KUIS), \\ Bandar Seri Putra, 43000 Kajang Selangor, Malaysia. \\ (Email: sitinoor@ kuis.edu.my)
}

Received date: 08-10-2019

Revised date: 14-11-2019

Accepted date: 15-11-2019

Published date: 15-12-2019

To cite this document: Hamid, N. A. A., Hassim, M. H., Ab Wahab, N., Aziz, T. N. R. A., Ramli, R., \& Ahmad, S. N. (2019). Alternative Dispute Resolution (ADR) via Sulh Processes. International Journal of Law, Government and Communication, 4(17), 25-33.

DOI: $10.35631 /$ ijlgc.417003

Abstract: Islam is sent by Allah S.W.T through His messenger, our beloved prophet Muhammad S.A.W and is seen as a complete and perfect religion to answer all of the problems faced by humankind on this earth. Its integrated and natural system can be implemented anywhere, anytime and in all situations. All of its rules and regulations are not against the natural norms and dispositions of humans. It is sent solely for the assurance in forming a harmonious life, free of quarrels and arguments that can cause chaos in the lives of humans. In our daily lives, we cannot help but face various difficulties, problems, misunderstandings, and disputes. Therefore, 
Islam cannot let its followers find the solution for such matters without providing a way out as well as instilling the spirit of Islam in it. When solving a dispute, Islam promotes a method based on the principle of 'al-Sulh' which simply means peace. Islam truly encourages the practice of sulh as it highlights efforts of peace-making through acceptance. Prophet Muhammad S.A.W very much encouraged his followers to seek peace and avoid having disputes with one another. There is an event involving Prophet Muhammad S.A.W. solving a dispute among the Quraisy dignitaries regarding the right to place the Hajar al-Aswad that proves the practice of sulh is very much promoted in Islam. This research uses the qualitative method and document analysis, literary research and scientific journals. The research is hoped to provide insights on the Alternative Dispute Resolution via sulh processes and its kind in the perspective of Islam.

Keywords: Alternative Dispute Resolution, Islam, Sulh, Conflict, Dispute

\section{Introduction}

Islam is sent by Allah S.W.T through His messenger, our beloved prophet Muhammad S.A.W and is seen as a complete and perfect religion to answer all of the problems faced by humankind on this earth. Its integrated and natural system can be implemented anywhere, anytime and in all situations. All of its rules and regulations are not against the natural norms and dispositions of humans. It is sent solely for the assurance in forming a harmonious life, free of quarrels and arguments that can cause chaos in the lives of humans. Islam stresses on the importance of justice and it must be implemented in all situations. In the efforts to resolve disputes fairly, the judge must begin with the effort to encourage disputing parties to make peace (Najibah, 2007). A peaceful dispute will be able to stop misunderstandings and altercations as well as strengthen relationships. Therefore, Islam very much encourages the disputing parties to resolve their problems through several ways of Alternative Dispute Resolution (ADR) involving sulh. ADR is a popular abbreviation used to refer to dispute resolution methods via negotiation, mediation, arbitration, mini trials and so on. ADR is part of the procedure that provides alternative ways to complicated litigation process and usually is aided by a neutral third party (Brown \& Marriot, 1999). In our daily lives, we cannot help but face various difficulties, problems, misunderstandings and disputes. Therefore, Islam cannot let its followers to find the solution for such matters without providing a way out as well as instilling the spirit of Islam in it.

\section{Literature Reviews}

\section{Alternative Dispute Resolution Processes in Islam}

Islam very much encouraged its followers to solve their disputes nicely without causing enmity later on. Thus, Islam promotes dispute resolutions which are almost similar and according to the laws of ADR. Below are several types of Alternative Dispute Resolution methods in Islam;

\section{Sulh (Negotiation or Mediation)}

Sulh is derived from the word salaha which means to do good. In other words, sulh is an agreement made by two parties on the grounds of specific terms that have been agreed upon during the resolution process (Ramizah, 2007). In Islam, the objective of sulh is to end a dispute occurred among Muslims so that their lives are ever peaceful and free from misunderstandings, revenge and prejudice. It is the process to stop the disputes. The sulh process is to take into account all opinions and situations of the parties involved. It simply means that it is the best method to voice out opinions and perspectives without being bound to strict procedures and 
litigation process. Resolutions made through this method are very much encouraged especially in issues related to familial disputes. This type of issues is very sensitive since it is closely related to the privacy rights of individuals, families and one's disgrace. If a case related to familial disputes is resolved through trial, it will surely expose the weaknesses of the people involved and their disgrace brought to light while their whole issue will be unearthed by the Judge. Sulh is a matter explained in detail in the Quran and recorded practices of the prophet Muhammad S.A.W. In the Quran, Allah S.W.T has mentioned it in verse An-Nisa' (4): 128:

"And if a woman fears from her husband contempt or evasion, there is no sin upon them if they make terms of settlement between them - and settlement is best. And present in [human] souls is stinginess. But if you do good and fear Allah - then indeed Allah is ever, with what you do, Acquainted."

And in An-Nisa (4) 114.

"No good is there in much of their private conversation, except for those who enjoin charity or that which is right or conciliation between people. And whoever does that seeking means to the approval of Allah - then we are going to give him a great reward."

\section{Tahkim (Arbitration)}

Historically, arbitration and amicable settlement (sulh) is not new in Shariah law and have a long history within Arab and Islamic societies and have their roots in pre-Islamic Arabia (alRamahi, 2008). From the Shariah law perspective, the arbitration is known as tahkim which has the function to resolve any disputes referred to it by conflicting parties. The word tahkim literally means, to entrust a third party neutral to adjudicate the dispute (Idid and Oseni, 2014). Technically, tahkim is an appointment by the disputing parties of someone to judge on a matter that both parties are in disputes. In other words, tahkim comes to the function when both disputing parties agree to appoint an arbitrator to settle the dispute that may raise or has arisen among them (Omar and Azam, 2018). Tahkim, linguistically means to provide the power of sentencing to someone. Term-wise, the definition of Tahkim is almost similar to its linguistic meaning since it refers to the process in which the disputing parties appoint someone to be a judge and resolve the dispute occurred according to Islamic laws. The appointed individual to judge the disputing parties is called 'hakam' or 'muhakkam'. The position of the tahkim is lower compare to the al-Qadha or judicial body. This is because a qadi or a judge can try cases that sometimes, cannot be tried by a hakam. The decision made by a hakam can only be enforced to those involved whether it is agreed upon or not. Tahkim is a system that has become a community practice among the jahiliyyah Arabs in which the disputing parties will appoint a trusted individual, in their opinion, to resolve the crisis that occurred (Abd al-Karim Zaydan, 1984). However, the jurisdiction involving the tahkim process has its own limitations. Not all matters of dispute can be solved through this process. Matters related to hudud cannot be solved through it. According to the Shafie school of thought, the tahkim process is not like a formal court and the judge or arbitrator appointed cannot be changed before an award is given. However, a contrasting opinion is given in the Hanbali school of thought. According to it, an arbitrator has equal power to a judge and the decision made by him is binding.

\section{Med-Arb (Sulh and Tahkim Combination)}

Med-Arb or known as Mediation-Arbitration is a process in which the parties involved will agree to solve disputes through mediation first, and if mediation fails, then the arbitration 
process will take over. This med-arb process is stated in the Quran, the holy words of Allah S.W.T (Surah al-Nisa: 58).

"Indeed, Allah commands you to render trusts to whom they are due and when you judge between people to judge with justice. Excellent is that which Allah instructs you. Indeed, Allah is ever Hearing and Seeing."

Based on the above, it is clearly stated that the role of an arbitrator is, firstly, to carry out the mediation process and if it fails, he will resort to the arbitration or tahkim process. This showed that Islam recognized the implementation of this med-arb process. Combining the arbitration and mediation processes creates a mechanism that is accepted and applied worldwide. In China, Japan, Korea, Vietnam and Malaysia, this process is practiced. According to Article 18 of the Rules of Korean Commercial Arbitration Board, the negotiation process can be done when the arbitration process is conducted. It opens the opportunity to parties to carry out the negotiation processes if according to them, a joint agreement can be achieved (Md Zahidul, 2012).

\section{Muhtasib (Ombudsman)}

The Enforcement Institution or ombudsman is first introduced in Sweden in 1809. In England, the ombudsman is governed under the Parliamentary Commission Act 1967. According to Islamic Law, the term al-muhtasib is similar to ombudsman. In Islam, the term al-muhtasib or enforcement has long been practiced for 1400 years ago in line with the coming down of the Quran. There are many instances in the Quran that focused on the al-muhtasib concept. The main purpose of the implementation of al-muhtasib is as an enforcement body that enforces all forms of religious activities such as the mandatory performing of prayers, avoiding forbidden activities and promote good deeds, processes related to governance and investigating misconducts. If thoroughly perused, the ombudsman seems dissimilar to the ADR process since the main ADR principle is to resolve disputes, but ombudsman is more inclined towards the investigation process. Since ombudsman, sometimes help in investigating complaints received from the community, therefore it can be classified as one of the branches of ADR.

\section{Fatwa (Expert Opinion)}

Fatwa is an opinion issued by an individual who is an expert in Islamic Law known as mufti. The one question arising here is, how does this fatwa institution can be classed as ADR? As understood, the mediation, arbitration, med-arb processes and others needed a third party to solve their disputes. History has proven that fatwa or mufti plays an effective role in solving disputes. Generally, the fatwa issued by a Mufti will be used as reasoning in determining a matter and it will lead to the formation of the latest legal principle and used as a platform to resolve disputes in the future.

Based on the discussion mentioned above, it is clear the ADR processes are not an alien and new notion in Islam. ADR is formed due to societal reactions that want their disputes to be solved faster without going through time-consuming trials in courts. Sharia Courts are established to assist the community to resolve problems faced by them especially issues involving Muslim familial matters such as divorce, child custody rights, maintenance, alimony (muta'ah), inheritance and others. These issues will be judged by Sharia Courts through the litigation process set as provided in the sharia law in Malaysia such as the Sharia Court Procedural Enactment/Act, and Muslim Families Law Enactment. Hammad (2016) explained that today, the public begins to complain and show their discontentment that the litigation process is starting to burden them with the costly expenses and time-consuming processes since 
most cases presented in front of the Judge are cases that needed fast and immediate decisions. For example, in the question of child custody, the need to obtain fast decisions in deciding the parent the child will stay with must be resolved quickly so the welfare of the said child can be preserved. Because of that, the out of court dispute resolution concept is gradually accepted by society. The sulh method has been introduced and implemented in Sharia courts in Malaysia. It is first introduced and implemented in the Selangor State Sharia Judicial Department in 2002 in which it priorities dispute resolution instrument via peace-making. This method is an alternative to the trial method that usually takes a long time to resolve and very costly. Besides Sharia Court implementing sulh, the Malaysia Bar is the first to establish a Mediation Center in 1999 to handle civil cases through the mediation concept.

The sulh method can be implemented in various forms but depending on the claims or application made by the disputing parties. This includes counseling (marriage counseling), Hakam and the Conciliator Committee in syiqaq or altercation issues in marital problems and the Sulh (mediation) Council or discussion by these parties either by themselves or through a representative or through their respective sharia lawyers for any claims or application involving the rights as well as responsibilities in Muslim familial affairs under the Sharia Court jurisdiction (Siti Noraini, 2008).

\section{Sulh Definition}

Linguistically, Sulh means ending disputes and create peace. (Ahmad Kamal al-Din, t.t). The term sulh always incline towards goodness. It can refer to a good, safe, wellness and peace besides being the antonym for words that have a negative meaning such as al-fasad and almukhasamah. Sulh is also a common term used in Islamic law since it technically ends any dispute that occur between any two parties (Su'aida, 2009). Al-Sharbini (t.t) has provided an explanation to the term as a contract made with the purpose to resolve issues between two disputing parties. The position of sulh in Islam is clear since it is one of the resolution methods encouraged to be used if a dispute occurs between two parties. There are many supporting statements on this matter that can be quoted from the Quran, hadiths, and consensus of Islamic scholars. This showed that Allah S.W.T promotes for the sulh concept to be practiced as it is a good resolution method in resolving disputes. Sulh as a means to end of the dispute or be understood as a peaceful resolution can be simply referred to an agreement between two parties based on certain terms agreed upon during the resolution process is going on. According to Ibnu Qudamah (1984), sulh refers to a joint agreement in order to bring peace between two disputing parties.

Based on the definition provided above, it can be concluded that sulh is a decision or result that is made from a treaty or agreement of two altercating and disputing parties. The Sulh Council is a guided negotiating process executed according to the rules set in Islamic law in order to achieve sulh (Section 99 (Selangor State) Sharia Court Procedural 2003). This method is not only cost and time-saving but also manage to resolve issues openly. Meanwhile, hakam is one of the judicial branches appointed according to Muslim Family laws that aim to resolve issues between husband and wife. The hakam or tahkim process is seen as the last resort to be taken if all initiatives to bring peace in a disputing couple have failed. The hakam helps to bring peace to a couple when they fail to solve their problems without external intervention.

Hakam is derived from the Arabic word, hakama yahkumu hukman which means law. Hakam, in English is known as arbitrator, arbiter, umpire or referee (Norzulaili \& Wan Abdul Fatah, 2006). According to the 2004 Sharia Court Practice Order, a hakam is a representative that is 
authorized by parties and appointed by the court to resolve issues and fights (syiqaq) between husband and wife. When a hakam is appointed, he must carry out his duties responsibly. The first thing that must be stressed on is being sincere in the name of Allah S.W.T so that the dispute resolution process of two disputing parties can run smoothly. Next, the hakam for both parties must go on with his task to bring peace to the disputing couple either through a joint or separated discussion. After inquiring about the truth of the matter from both husband and wife, the hakam cannot withhold any information obtained from the couple. He must be fair and unbiased. In reflection, it can be seen that the Hakam, sulh and the Conciliator Committee possess the same function but each one has their own definition, such as:

1. The Conciliator Committee Member is not limited to the representative of a husband or wife but can be more than two people. However, the hakam must consist of two people, one representing the husband and one representing the wife.

2. The condition that enables a Conciliator Committee to be appointed is when one of the parties does not agree to a divorce or the court feels that there is high probability the marriage can be saved. This differs to the hakam. His big role is given by the State Muslim Family Law Enactment in which it is stated they can resolve familial disputes (syiqaq).

3. The appointment period of a Conciliator Committee is between three to six months. It is different for a hakam, since no time limit is set if there are chances for the couple to make peace.

4. The Conciliator Committee is only authorized to report suggestions, but it depends on the court's jurisdiction to make any decision. However, a hakam is given full power to announce divorce (talak) or accept a divorce retraction if he is representing the husband.

\section{Categories Of Sulh}

Sulh can be classified to three main categories which are:

\section{Sulh Through Vows}

Sulh through vows involve someone make claims upon another person about a debt involving something with value. Therefore, the one who is accused will confirm the claim made and later, both parties make peace when the one making the claim takes something from the accused. It is because no one has any restrictions to themselves in absolving his rights or part of his rights (Abdul Munir, 2000).

Prophet Muhammad S.A.W, in a narration made by Nasa'ie and others from Ka'ab Bin Malik when he asked for his dues from Abdullah Bin Abi Hadrat in a mosque loudly until he is heard by Prophet Muhammad S.A.W when the holy prophet is at home. He then opened his window and called out to Ka'ab. Ka'ab replied: "O' Prophet!" The Prophet then commanded, "Release him from your debt by giving him a condition. Ka'ab replied: "I have done what you asked, O' Prophet and which the prophet said, it has been completed".

So, when the accused confirms that he took monetary debts, resolution made must be done with money too and is assumed to be paid off with conditions. And if he confirms but he pays his debts with materials or vice versa, it will be seen as a sale and judged to the law accordingly. If 
he confirms that he took monetary or material debts, then it must be seen as an act of rental and is binded to the laws of rental.

\section{Sulh Through Objection}

Sulh through objection happens when someone claims his rights from another regarding money, things or something of value but the latter objects or refuse or disagree with the claim. The two parties must make peace by instructing the accused to pay half of the claims made. This is a common practice (ghalib) in any dispute that occurred between two people. It is a method that must be used according to the followers of Islamic schools of thought such as Maliki, Hanafi and Hanbali but not according to the scholars under the school of thought of Shafie.

\section{Sulh Without Statement}

The third category of sulh is called the silent sulh. It happens when someone claims another person of owing a property, money or anything of value but the latter keeps silence, neither confessing nor denying. Later, both will commit sulh. This method is seen as acceptable by most scholars but not according to Shafie's school of thought (Wahbah, t.t). The conditions for sulh is the proclamation of ijab (offer) and qabul (acceptance) with whatever that can give the meaning of resolution and peace as the accused (al-mudda'a alaih) said to the one making the claim (al-mudda'ai); "I make peace and resolved with you of all rights and whatever that belongs to you with value of one hundred with this payment of fifty ringgit" and followed by an answer by the one making the claims; "I accept". Peace-making or sulh binds the parties involved and cannot be changed without an agreement and a second claim cannot be made. Sulh can be made before or after a claim is made in court.

\section{Conditions For Sulh}

According to Syeikh Ghazali (2000), as agreed by a majority of scholars, there are four conditions of sulh which are: two people making declarations, a contract, dispute matter and sulh replacement. From these conditions, there are three terms of sulh:

(1) Terms related to the parties making peace (sulh):

(a) Individuals who are eligible and lawful to donate their property. If it is made by inelligible persons such as a mentally unstable person or a child or a guardian of an orphan or a waqf nazir (inspector or supervisor), then the sulh made is not legal since it is a form of donation and they do not own the sulh given.

(b) Nonetheless, sulh made by a guardian of an orphan or waqf nazir (inspector or supervisor) is legal if the sulh made can benefit the orphan and waqf property.

(2) Terms to make something sulh:

(a) Property that can be valued and can be passed or valuable.

(b) Its existence known and cannot be questioned in order to execute the acceptance and submission process.

(3) Terms for disputed rights:

(a) Property that can be valued or beneficial.

(b) It is a right of a person that must be replaced even if it is not in a form of property such as qisas.

(c) Allah's rights are not eligible to be made into sulh such as adultery and imbibing alcohol.

Based on the terms and conditions above, the results, if the sulh is agreed upon, is binding and unchangeable without agreement and the claims made cannot be heard twice. However, a resolution made in the Sulh Council can be brought to court if there is insincerity, fraud, mistakes and others that can cause injustice to one party. 
Generally, resolution through the sulh method, in the eyes of the law and implemented, occurred in two categories of sulh explained by (al-Bajuri, t.t) which are renunciation (ibra') where the applicant (claiming the right) is willing and agree to accept part of the claim made; and replacement (mu'awadhah) where the applicant does not take the right claimed but agree for it to be replaced in another form. Norita (2016) explained in detail the types of disputes that can be resolved through sulh:

1) Sulh between Muslims and non-Muslims in which the proclamation is stated in chapters al-jizyah and al-aman, as seen in the words of Allah SWT (Al-anfal 8: 61)

2) Sulh between ruler and rebel as seen in the words of Allah SWT (Al-Hujurat 49: 9)

3) Sulh in proclamations mentioned in the commercial transaction chapter (muamalat) that becomes the main source of debate in the sulh concept.

4) Sulh between husband and wife mentioned in the al-shiqaq chapter as seen in the words of Allah S.W.T (An-Nisa' 4: 128)

5) Sulh between two disputing partied in other matters such as qisas.

\section{Conclusion}

Islam stresses on the importance of justice and it must be implemented in all situations. In the efforts to resolve disputes fairly, the judge must begin with the effort to encourage disputing parties to make peace. A peaceful dispute will be able to stop misunderstandings and altercations as well as to strengthen the relationships. Among the resolutions on issues made include issues related to war, rebellion (crime), commercial transaction (property), families or other rights allowed by the law. Therefore, Islam very much encourages the disputing parties to resolve their problems through several ways as the Alternative Dispute Resolution including sulh. All forms of sulh in discussion showed that Islam highly encourages disputing parties, in whatever issues they face, to resolve it peacefully through a joint agreement (sulh) and the execution of sulh must be binded to the type of issue that cause the dispute to occur, in making sure the process gain good and peace result on both disputing parties.

\section{References}

Al-Quran and As-Sunnah

Abd al-Karim Zaydan (1984) Nizam al-Qadha fi al-Syariah al-Islamiyyah. Baghdad: Matba'ah al'Ani.

Abdul Munir Yaacob et al. (2000) Undang-Undang Keluarga Islam dan Wanita di NegaraNegara Asean. Kuala Lumpur: Institut Kefahaman Islam Malaysia.

Ahmad Kamal al-Din Muhammad bin Abd al-Wahid ibn Humman. (T.t) Takmilah Syarh Fath al-Qadir ala al-Hidayah Syarh Bidayah al-Mubtadi li al-Marghinani. Dar al-Fikri. Jil.8.

Al-Bajuri, Ibrahim, Hashiyah Bajuri, al-Haramain, Vol 1.

Al-Ramahi, A. (2008). Sulh: A Crucial Part of Islamic Arbitration. LSE Legal Studies Working Paper No. 12/2008; Islamic Law and Law of the Muslim World Paper No. 08-45. Available: https://ssrn.com/abstract $=1153659$

Al-Sharbini. Mughni al-Muhtaj. Jil.2.

Hammad Dahalan \& Mohamad Azhan Yahya (2016) Kedudukan Pegawai Sulh Di Mahkamah Syariah. International Conference on Aqidah, Dakwah and Syariah 2016(IRSYAD 2016. 
H.J.Brown and A.L.Marrriot, Q. C, ADR Principles and Practice, Sweet \& Maxwell, London, 1999, Second Edition.

Ibnu Qudamah. (1984). Al-Mughni. Jil 4. Makkah: Maktabah Tijariyyah.

Idid, S. A. and Oseni, O. A. (2014). Appointing a Non-Muslim as Arbitrator in Tahkim Proceedings: Polemics, Perceptions and Possibilities. Malayan Law Journal, 5: 16-18

Md. Zahidul Islam (2012) Provision of Alternative Dispute Resolution Process in Islam. IOSR Journal of Business and Management. Volume 6 Issue 3 (Nov-Dec 2012).

Najibah Mohd Zain et al. (2007) Undang-Undang Keluarga (Islam). Kuala Lumpur: Dewan Bahasa Dan Pustaka.

Norita Kamaruddin (2016) Konsep Sulh Menurut Perspektif Islam Dan Aplikasinya Dalam Mahkamah Syariah Di Malaysia. Kertas kerja dibentangkan di International Conference on Aqidah, Dakwah and Syariah 2016 (Irsyad 2016).

Omar Saleh Abdullah Bawazir, Mohammad Azam Hussain (2018). The Qualifications of Arbitral Tribunal: Perspectives of Shariah Law and UNCITRAL Model Law. The Journal of Social Sciences Research. Special Issue. 6, pp: 1213-1217, 2018.

Ramizah Wan Muhammad (2007) Sulh Sebagai Alternatif Penyelesaian Kes di Mahkamah Syariah dlm Kaedah Perundangan Dan Bidang Kuasa Dan Tatacara Mahkamah Syariah. Kuala Lumpur: Dewan Bahasa Dan Pustaka.

Sheikh Ghazali bin Haji Abdul Rahman. Sulh Dalam Perundangan Islam. Jurnal UndangUndang IKIM, Vol 4, and No 2.

Siti Noraini Bt Haji Mohd Ali. (2008) Perlaksanaan Sulh Dan Aplikasinya Di Jabatan Kehakiman Syariah Negeri Selangor. [2008] 3 ShLR i.

Su'aida Safei (2009) Majlis Sulh (Islamic Mediation) In the Selangor Syariah Court and Malaysian Mediation Centre of the Bar Council: A Comparative Study. [2009] 5 MLJ lxxxiii.

\section{Statutes}

Enakmen Tatacara Mal Mahkamah Syariah (Negeri Selangor) 2003.

Enakmen Undang-Undang Keluarga Islam (Negeri Selangor) 2003.

Kaedah-Kaedah Tatacara Mal (Sulh) Wilayah-Wilayah Persekutuan 2004.

Parliamentary Commission Act 1967 (England).

Rules of the Korean Commercial Arbitration Board.

Rules of Maritime Arbitration of the Japan Shipping Exchange.

Arahan Amalan Jabatan Kehakiman Syariah Malaysia No.1 Tahun 2010.

Arahan Amalan No 5 Tahun 2010.

Arahan Amalan Jabatan Kehakiman Syariah Malaysia No.9 Tahun 2015.

Arahan Amalan Jabatan Kehakiman Syariah Malaysia No.2 Tahun 2012.

Arahan Amalan Jabatan Kehakiman Syariah Malaysia No. 4 Tahun 2011

*For correspondence; Tel. + (60) 193096889, E-mail: noradha@kuis.edu.my 